HELMINTHOLOGIA, 58, 3: 248 - 262, 2021

\title{
Comparative comprehensive analysis on natural infections of Hymenolepis diminuta and Hymenolepis nana in commensal rodents
}

\author{
S. K. BRAR ${ }^{1}$, N. SINGLA ${ }^{1 *}$, L. D. SINGLA ${ }^{2}$ \\ 1Department of Zoology, Punjab Agricultural University, Ludhiana-141004, Punjab, *E-mail: neenasingla1@gmail.com, \\ neenasingla@pau.edu; 'Department of Veterinary Parasitology, Guru Angad Dev Veterinary and Animal Sciences University, \\ Ludhiana-141004, Punjab
}

Article info

Received June 13, 2020

Accepted March 29, 2021

\section{Summary}

This first comprehensive report from Punjab province of India relates to patho-physiological alterations alongwith morpho-molecular characterisation and risk assessment of natural infections of Hymenolepis diminuta and Hymenolepis nana in 291 commensal rodents including house rat, Rattus rattus $(n=201)$ and lesser bandicoot rat, Bandicota bangalensis $(n=90)$. Small intestine of 53.61 and $64.95 \%$ rats was found infected with $H$. diminuta and $H$. nana, respectively with a concurrent infection rate of $50.86 \%$. There was no association between male and female rats and $H$. diminuta and $H$. nana infections $\left(x^{2}=0.016\right.$ and 0.08 , respectively, d.f. $\left.=1, P>0.05\right)$, while the host age had significant effect on prevalence of $H$. diminuta and $H$. nana $\left(x^{2}=28.12\right.$ and 7.18 , respectively, d.f. $=1$, $P \leq 0.05)$ infection. Examination of faecal samples and intestinal contents revealed globular shaped eggs of $H$. diminuta without polar filaments $(76.50 \pm 3.01 \mu \mathrm{m} \times 67.62 \pm 2.42 \mu \mathrm{m})$, while smaller sized oval eggs of $H$. nana were with $4-8$ polar filaments $(47.87 \pm 1.95 \mu \mathrm{m} \times 36.12 \pm 3.05 \mu \mathrm{m})$. Cestode infection caused enteritis, sloughing of intestinal mucosa, necrosis of villi and inflammatory reaction with infiltration of mononuclear cells in the mucosa and submucosa. Morphometric identification of the adult cestodes recovered from the intestinal lumen was confirmed by molecular characterisation based on nuclear ITS-2 loci which showed a single band of $269 \mathrm{bp}$ and $242 \mathrm{bp}$ for $\mathrm{H}$. diminuta and $H$. nana, respectively. Pairwise alignment of the ITS-2 regions showed $99.46 \%$ similarity with sequences of $H$. diminuta from USA and $100 \%$ similarity with sequences of $H$. nana from Slovakia, Kosice.

Keywords: Cestode; histopathology; Hymenolepis; molecular; parasite; rodents

\section{Introduction}

Rats are the most successful and significant mammals as they have high proliferation rate and adaptable capacity to different habitats and environmental conditions (Meerburg et al., 2009; Singla et al., 2016). Nevertheless, rodents cannot legitimately cause diseases in humans, but transmit disease pathogens if they come in contact with rodent excrements such as urine, faeces, hair and saliva (Singla et al., 2008a; Meerburg, 2010).
Over 400 Hymenolepis species are found occurring in higher vertebrates throughout the globe in temperate to tropical areas (Bahadir, 2002). Hymenolepiasis, a global zoonotic disease caused by $H$. diminuta and $H$. nana is not uncommon in wild and laboratory rats (Waugh et al., 2006; Singla et al., 2008b; Singla et al., 2016). Both $H$. diminuta and $H$. nana have been reported in rats, mice and humans particularly the children (Alvez et al., 2003). The parasitization rates of $H$. diminuta in humans range from $0.001-5.5 \%$ in different parts of the world (Watwe \& Dardi, 2008). Since the

\footnotetext{
* - corresponding author
} 
initial random coprological studies on 10,000 human stool samples revealing $0.23 \%$ samples positive for eggs of $H$. diminuta in India (Chandler et al., 1923), sporadic cases of hymenolepiasis have been frequently reported from India (Watwe \& Dardi, 2008) as well as from other parts of the globe (Marangi et al., 2003).

Hymenolepis nana is the most common human dwarf tapeworm with an estimate of up to 75 million persons infected worldwide. Its prevalence among children is as high as $25 \%$ (Crompton, 1999). Mirdha \& Samantary (2002) found $9.9 \%$ prevalence of $H$. nana among urban slum dwellers in India. Recently, 24 year old pregnant women presented with symptoms of vomiting and abdominal pain was found infected with $H$. nana on stool examination (Kandi et al., 2019).

Besides causing mortality in humans and animals, the parasites can complicate the health status by inducing alterations in physiological and immunological mechanisms of the host resulting into tissue damages, stimulating abnormal tissue growth, competing with the host for nutrients, decreasing the volume of host's blood and body fluids and by mechanical interference (Hsu, 1980; Aboel-Hadid \& Allam, 2007).

The diagnosis of gastrointestinal parasites has traditionally depended on faecal microscopy which has low diagnostic sensitivity (Stensvold et al., 2007) leading to substantial under reporting of the parasites. The use of molecular tools in research and routine diagnostics play an important role in our understanding of epidemiology and transmission (283). Molecular characterization is being used increasingly to distinguish among morphologically similar parasites (Morgan \& Blair, 1998). With the improvement of techniques like polymerase chain reaction (PCR) based assays in stool and tissue samples for pathogenic parasite identification, it is possible that gastrointestinal parasite identification will become more sensitive and objective (Mejia et al., 2013). PCR with DNA sequencing permit the identification of species, strains and populations from a small quantity of tissue from any stage in their life-history (Morgan \& Blair, 1998).

Morphological and molecular studies of $H$. diminuta and $H$. nana are scarce, especially considering that these parasite species are cosmopolitan and widely distributed in anthropogenic environments (Fitte et al., 2018). As Hymenolepis species are of zoonotic importance, phylogenic study of these parasites is of particular importance. The analyses of the distribution of each hymenolepidid species may be useful for determining the potential health risks for humans, and to locate the highest risk areas. Furthermore, molecular studies for hymenolepidid cestodes are required to confirm their identifications and to analyse the levels of genetic variation and differentiation. The aim of present study was to analyse the prevalence in relation to environmental and host factors, patho-physiological alterations and morpho-molecular characterisation of hymenolepididae species of zoonotic importance in a comprehensive manner for the first time from urban commensal rodents in Punjab state of India.

\section{Material and Methods}

\section{Collection and maintenance of rodents}

A total of 291 commensal rodents of two species ( $201 R$. rattus and $90 \mathrm{~B}$. bengalensis) identified on the basis of characteristic morphological features were live-captured from residences/shops, poultry farms and fish market using single- and multi-catch rat traps in winter (November - February), summer (March - June) and monsoon (July - September) seasons between November 2017 to October 2019 at Ludhiana in Punjab Province of India. The sampling was done in a systematic way. In each season about 50 rodents were captured per year using $10-12$ single catch live traps (placed for $2-3$ nights) at monthly intervals. The study areas were not uniformly and largely infested with rodents and approval of maximum 300 rats was granted by Institutional Animal Ethics Committee of Guru Angad Dev Veterinary and Animal Sciences University, Ludhiana, Punjab, India. Trapping was carried out by placing traps along the walls and on rodent runways. Chapatti (Indian bread) pieces as lure were used in the single-catch rat traps, whereas, in multi catch rat traps, bait consisting of loose mixture of cracked wheat grains, edible vegetable oil and powdered sugar in 96:2:2 (WSO) was used as lure. After capture, all the animals were brought to the laboratory on the same day, kept individually in laboratory cages for 10 - 15 days with food and water provided ad libitum prior to initiation of the experiment.

\section{Collection and identification of parasites}

In the laboratory, faecal samples of all the live rodent specimens were collected and examined microscopically by floatation method for the presence of eggs and proglottids of adult worms of hymenolepidid species (Soulsby, 1982). This was done to compare the results of coproparasitoscopical technique and gastrointestinal examination. Faeces $(2-4 \mathrm{~g})$ were triturated in pestle and mortar using saturated salt (sodium chloride) solution. The mixture was strained through a tea strainer to collect the fluid in a small glass beaker. The fluid was then poured into small glass vials which were filled upto the brim. A cover slip was placed at the top of the vial. Then waited for $20-30$ minutes, removed the cover slip from the top and placed on a glass slide for examination under the light microscope.

Eggs of different kinds found on the slide were photographed for later identification. Morphometric measurements of the eggs were also made. Then all the animals were sacrificed using over dose of Thiopentone and dissected via a midventral incision to expose the viscera. To collect parasites, small and large intestines were taken out in large petri dishes containing $0.9 \%$ saline solution and cut longitudinally to release the contents. The contents were examined both with the naked eye as well as under a hand lens and light microscope for morphological characterisation of hymenolepidid species. Collected adult parasites were counted, photographed and preserved in $70 \%$ ethanol for later identification. From the data obtained, percentage of hosts infected, mean intensity and 
mean abundance of parasites were determined as per the formulae described in Bush et al. (1997) are given below:

Percentage of hosts infected $=\frac{\text { Number of hosts infected }}{\text { Number of hosts examined }} \times 100$

Mean intensity $=\frac{\text { Number of parasites }(\text { particular species })}{\text { Number of hosts infected (particular host species) }}$

Mean abundance $=\frac{\text { Number of parasites }(\text { particular species })}{\text { Number of hosts examined (particular host species) }}$

Histopathology of intestine

A small portion of intestine of infected rats was excised, fixed in bouin's fluid for 48 hours and processed into paraffin wax (Luna, 1968). Sections of $5 \mu \mathrm{m}$ were routinely cut, stained with hematoxylin and eosin (H\&E) and studied under light microscope.

\section{Molecular characterisation}

Genomic DNA of the adult parasites preserved in $70 \%$ ethanol was extracted using QIAamp tissue kit (Qiagen, Hilden, Germany) as per the manufacturer's protocol with slight modifications. The parasites were mechanically disrupted by using sterile pestle-mortar. Final elutions of DNA were made in $20-100 \mu$ of elution buffer. For detection of $H$. diminuta and $H$. nana, the genomic ribosomal DNA extracted from the adult parasites was used in PCR to amplify the internal transcribed spacer regions (ITS-2). Primers used for detection of both $H$. diminuta (forward 5 '-AGG TAT TAT CAC AGC CAT TGC CA-3' and reverse 5'- AGG CCA CGG TTA GTG AAC TG-3') and $H$. nana (forward 5'-CTG TCT GAG CGT CGG CTT AT-3' and reverse 5'- CTA GCG CAT AGC GAC TGA CA-3') were self-designed using Primer-BLAST. A total reaction volume of $25 \mu \mathrm{l}$ was used for PCR amplification. The PCR profile was as follows: initial denaturation for 5 minutes at $95^{\circ} \mathrm{C}$ followed by 35 cycles of denaturation for 45 seconds at $95^{\circ} \mathrm{C}$, annealing for 45 seconds at $52^{\circ} \mathrm{C}$ for $\mathrm{H}$. diminuta and at $54^{\circ} \mathrm{C}$ for $\mathrm{H}$. nana and extension for 45 seconds at $72^{\circ} \mathrm{C}$, and after 35 cycles a final extension step for 5 minutes at $72^{\circ} \mathrm{C}$.After the PCR cycles, end product was kept on hold at $4^{\circ} \mathrm{C}$. During each amplification reaction, a no template control was also included in each plate as negative control for PCR.

Amplification products were analyzed on $1.5 \%$ agarose gel and visualized by ethidium bromide staining. PCR products were purified using QIAquick@ PCR purification kit as per the manufacturer's protocol. The identity of PCR product was confirmed after sequencing from Xcleris Genomics, Ahmadabad, Gujarat, India and putting sequences obtained to Basic Local Alignment Search Tool (BLAST 2.2.22). Then the sequences were aligned using Clustal Wmultiple alignment tool with the default gap. All positions containing gaps and missing data were eliminated (complete deletion option). The phylogenetic tree was constructed by comparing the ITS sequences of the both the cestode species i.e. $H$. diminuta and $H$. nana with other available cyclophyllidean cestode sequences from GenBank using Maximum Likelihood method and Hasegawa-Kishino-Yano modelin MEGAX (Hasegawa et al., 1985; Kumar et al., 2018). Branch support was given using 1000 bootstrap replicates (Malsawmtluangi et al., 2011). The bootstrap consensus tree inferred from 1000 replicates was taken to represent the evolutionary history of the taxa analyzed (Felsenstein, 1985). Evolutionary analyses were conducted in MEGA X (Kumar et al., 2018).

\section{Statistical analysis}

Season, location, host species, sex and age wise comparison of data was made using chi-square test at $5 \%$ level of significance.

\section{Ethical approval and/or informed consent}

For the purposes of the present study, approval from Institutional Animal Ethics Committee for use of animals was obtained vide memo no. IAEC/2018/1153-1188 under Protocol no. GAD-

Table 1. Infection rates of adult parasites of $H$. diminuta and $H$. nana in commensal rodents when found alone and in concurrence to each other.

\begin{tabular}{|c|c|c|c|c|c|c|}
\hline $\begin{array}{l}\text { Rodents } \\
\text { species }\end{array}$ & $\begin{array}{l}\text { Endoparasites } \\
\text { Found }\end{array}$ & $\begin{array}{l}\text { Number } \\
\text { of host } \\
\text { infected }\end{array}$ & $\begin{array}{l}\text { Percent host } \\
\text { infected }\end{array}$ & $\begin{array}{c}\text { Number of } \\
\text { parasites } \\
\text { found }\end{array}$ & $\begin{array}{c}\text { Mean } \\
\text { intensity }\end{array}$ & $\begin{array}{c}\text { Mean } \\
\text { abundance }\end{array}$ \\
\hline \multirow{3}{*}{$\begin{array}{l}\text { Rattus rattus } \\
\quad(n=201)\end{array}$} & H. diminuta & 106 & 52.73 & 238 & 2.24 & 1.18 \\
\hline & H. nana & 128 & 63.70 & 575 & 4.49 & 2.86 \\
\hline & $\begin{array}{l}\text { Concurrent } \\
\text { infection }\end{array}$ & 102 & 50.74 & 613 & 6.01 & 3.04 \\
\hline \multirow{3}{*}{$\begin{array}{l}\text { Bandicota } \\
\text { bengalensis } \\
\quad(n=90)\end{array}$} & H. diminuta & 50 & 55.55 & 112 & 2.24 & 1.24 \\
\hline & H. nana & 61 & 67.78 & 285 & 4.67 & 3.16 \\
\hline & $\begin{array}{l}\text { Concurrent } \\
\text { infection }\end{array}$ & 46 & 51.11 & 265 & 5.76 & 2.94 \\
\hline$(n=291)$ & Overall & 197 & 67.70 & 1210 & 6.14 & 4.15 \\
\hline
\end{tabular}




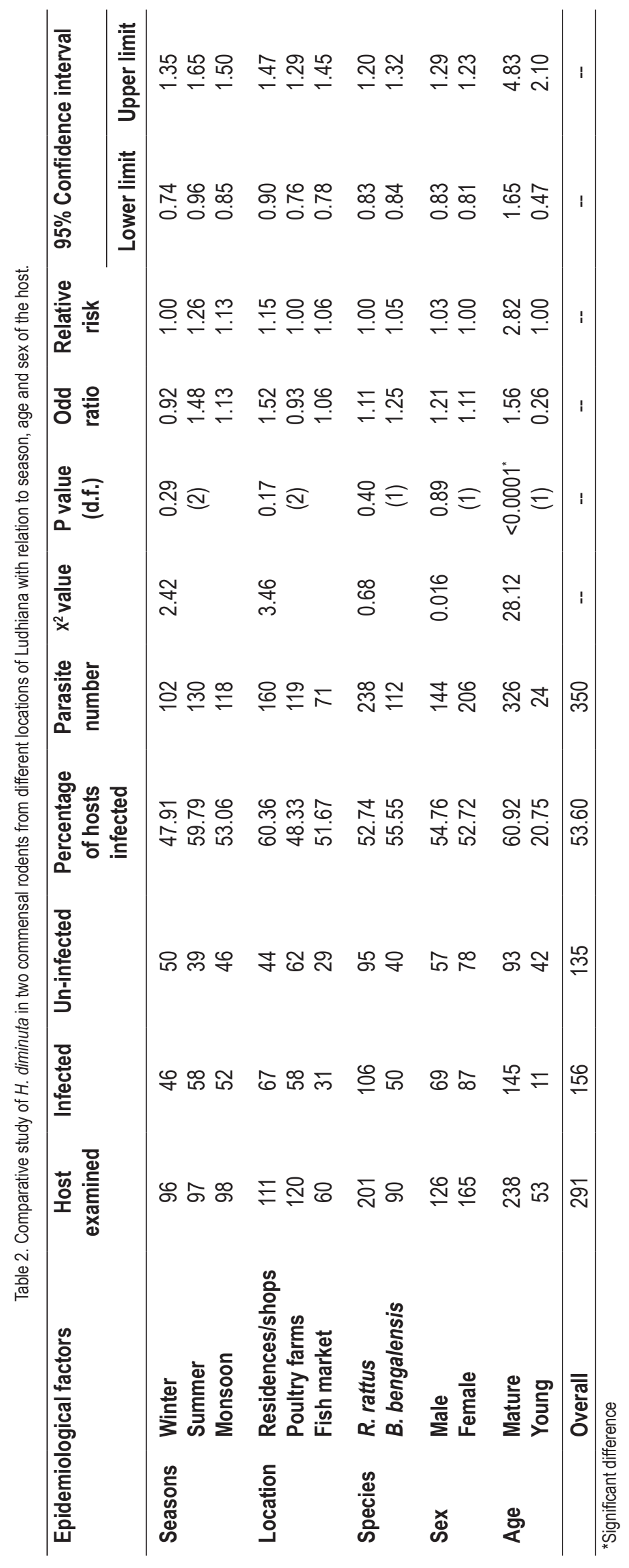




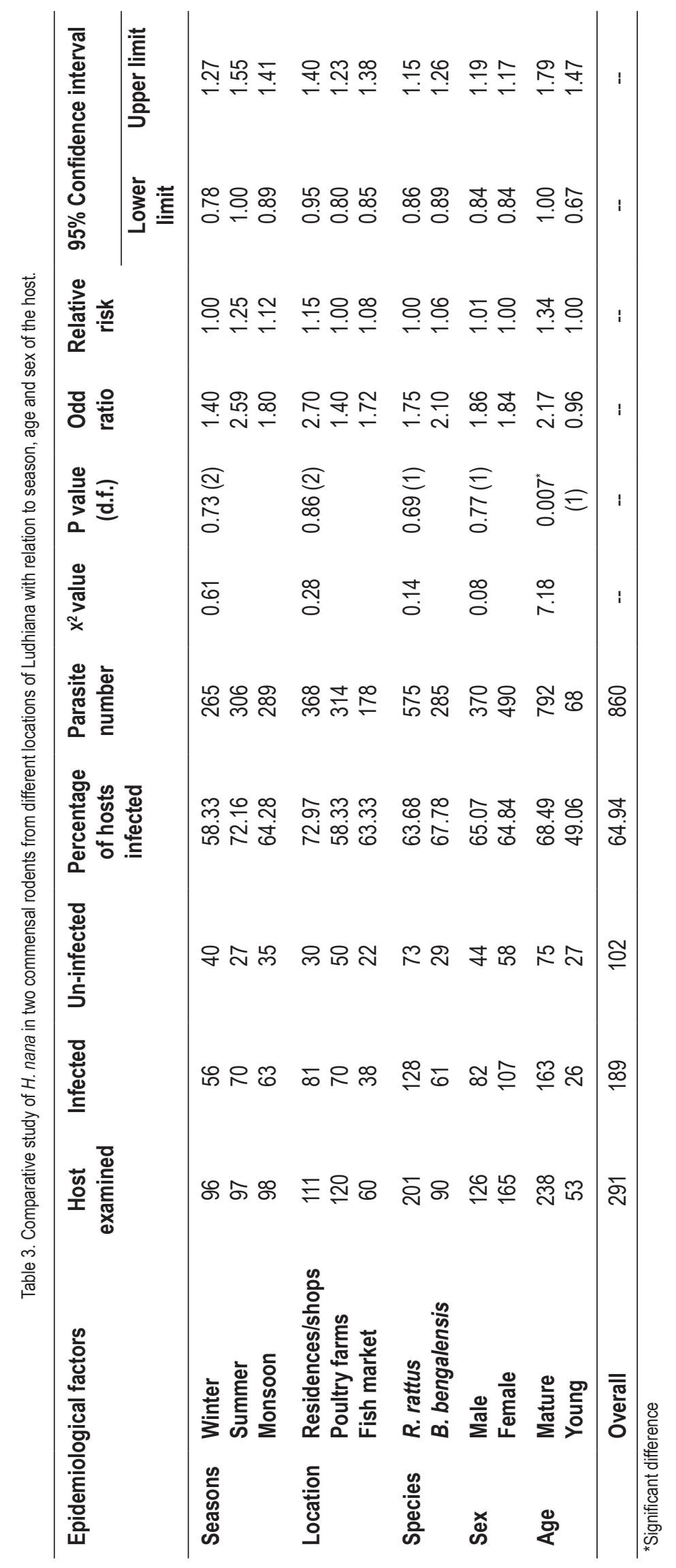




\begin{tabular}{|c|c|c|c|c|c|}
\hline \multirow[t]{3}{*}{ Cestode species } & \multicolumn{4}{|c|}{ Egg dimensions (Mean $\pm S D$ ) } & \multirow{3}{*}{$\begin{array}{c}\text { Standard size of } \\
\text { eggs }(\mu \mathrm{m}) \\
\text { (Wharyet al., 2015) }\end{array}$} \\
\hline & \multirow{2}{*}{$\begin{array}{c}\text { Length }(\mu \mathrm{m}) \\
\text { (Range) }\end{array}$} & \multirow{2}{*}{$\begin{array}{c}\text { Breadth }(\mu \mathrm{m}) \\
\text { (Range) }\end{array}$} & \multicolumn{2}{|c|}{ Average } & \\
\hline & & & Length $(\mu \mathrm{m})$ & Breadth $(\mu \mathrm{m})$ & \\
\hline H. diminuta & $72.75-80.25$ & $64.75-70.50$ & $76.50 \pm 3.01$ & $67.62 \pm 2.42$ & $70-85 \times 60-80$ \\
\hline H. nana & $45.75-50.00$ & $32.00-40.25$ & $47.87 \pm 1.95$ & $36.12 \pm 3.05$ & $40-60 \times 30-50$ \\
\hline
\end{tabular}

VASU/2018/IAEC/46/16 and no informed consent was required from the study participants and no informed consent was required from the study participants.

\section{Results}

Out of the total 291 commensal rodents analysed from different study locations during a period of two years, 197 (67.70\%) were found infected with hymenolepidid cestodes of two species, $\mathrm{H}$. diminuta and $H$. nana. Small intestine of 53.61 and $64.95 \%$ rats was found infected with $H$. diminuta and $H$. nana, respectively with a concurrent infection rate of $50.86 \%$. Overall, mean intensity and mean abundance due to these two cestode parasites were 6.14 and 4.15 , respectively (Table 1). Total 813 and 397 parasites of two species were found in $R$. rattus and $B$. bengalensis, respectively. Specimen parasites were mostly found in the anterior portion of the small intestine of rodents either as single species or in concurrence with each other (Table 1).

Prevalence in relation to different epidemiological factors

Comparison of seasonal infection and hence the relative risk of both $H$. diminuta and $H$. nana in rodents revealed highest infection rate in summer followed by monsoon and winter seasons, respectively. Statistically seasons had no significant effect $(P>0.05)$ on $H$. diminuta and $H$. nana infections in rodents (Tables 2, 3).

There was apparently higher infection of $H$. diminuta and $H$. nana in rodents captured from residences/shops followed by fish market
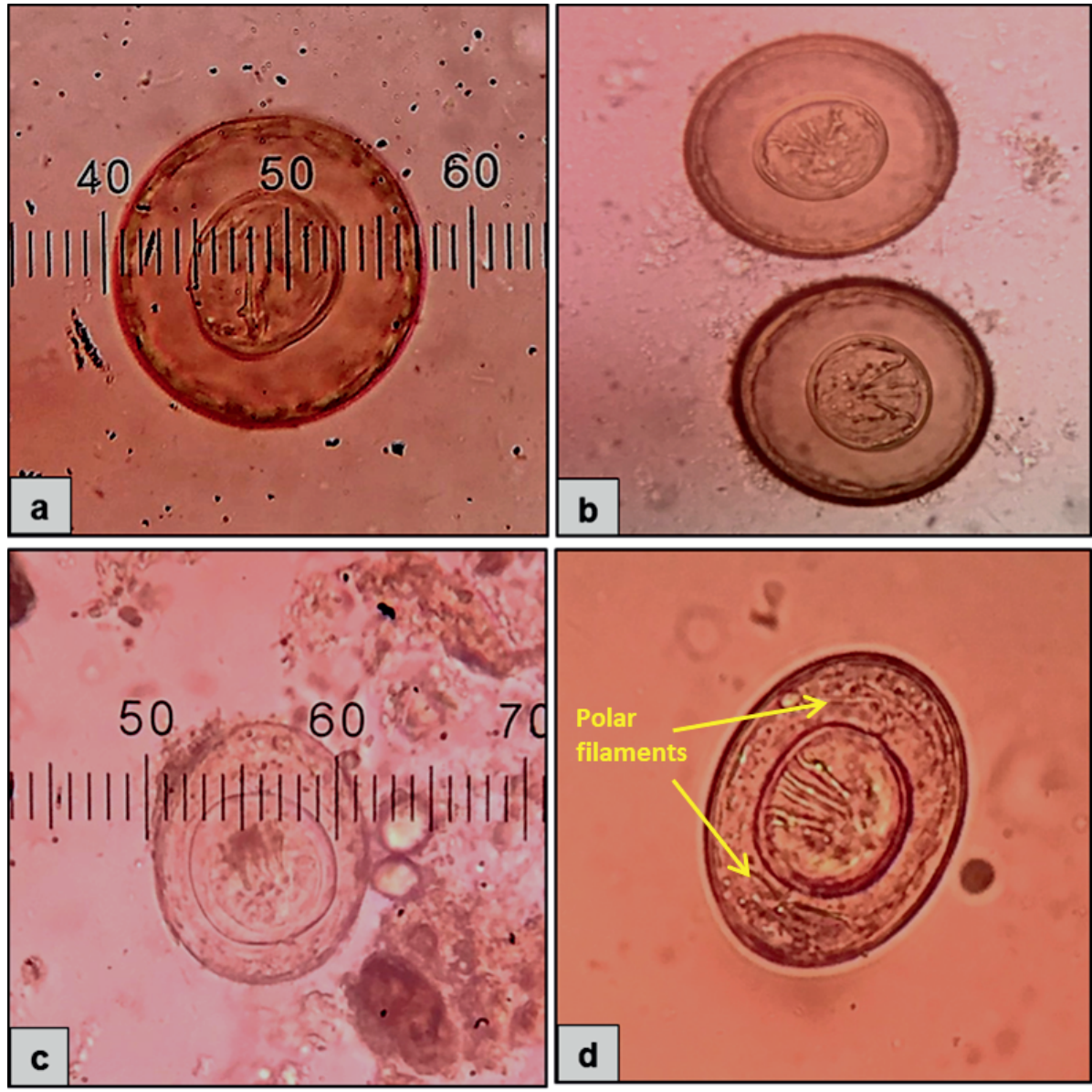

Fig. 1. Eggs of $H$. diminuta in an unstained wet mount of the faecalsample showing presence of hooks in the oncosphere and no polar filaments at $40 \mathrm{x}$ (a \& b); Eggs of $H$. nana in an unstained wet mount of the faecal sample showinghooks in the oncosphere and polar filaments within the space between the oncosphere and outer shell at $40 x$ (c \& d) 
and poultry farms, respectively but statistically there was found no significant effect $(P>0.05)$ of location on incidence of $H$. diminuta and $H$. nana infections (Tables 2,3 ) and hence the relative risk. Infection of $H$. diminuta and $H$. nana in $B$. bengalensis was 55.55 and $67.78 \%$, while in $R$. rattus it was 52.73 and $63.70 \%$, indicating no significant effect of rodent species on $\mathrm{H}$. diminuta and $H$. nana infections (Tables 2,3 ). The relative risk of infection was almost similar in $B$. bengalensis and $R$. rattus (Table 2, 3).

The present study also indicate that the infection of $H$. diminuta and $H$. nana in males and their female counterparts is almost similar indicating no association between host sex and $H$. diminuta and $H$. nana infections (Tables 2, 3).

Higher infection of $H$. diminuta and $H$. nana was recorded in mature rats as compared to young rats. Statistically the age had significant effect on infection rate of $H$. diminuta $(P<0.0001)$ and $H$. nana $(P=0.007)$ (Table 2, 3). Relatively higher risk of infection of $H$. diminuta and $H$. nana was observed in mature rats than in young rats (Tables 2, 3).

\section{Eggs of cestode parasites and morphometery}

Examination of the faecal samples of captured rodents revealed the presence of numerous eggs of $H$. diminuta and $H$. nana. Under microscope, globular shaped eggs of $H$. diminuta were seen (Ta- ble 4). Hexanth embryo present within the oncosphere was without any polar filaments (Fig. 1a, b).

The eggs of $H$. nana were oval and smaller than those of $H$. diminuta (Table 4). Hexacanth embryo within the oncosphere was contained 4 - 8 polar filaments extending into the space between the oncosphere and the outer shell (Fig.1c, d). Eggs of both $H$. diminuta and $H$. nana were found in different development stages alone as well as in concurrence with each other in the faecal samples.

\section{Morphometric analysis of adult parasites}

Morphological and morphometric characters of adult parasites of both the species were compared to support their identification. Examination of $H$. nana revealed $2-4 \mathrm{~cm}$ long tapeworms (Fig. 2a) having scolex (length between $0.90-1.60 \mathrm{~mm}$ ) with four suckers (diameter ranged of $0.20-0.50 \mathrm{~mm}$ ) and a rostellum (length varied from $0.60-1.10 \mathrm{~mm}$ ) armed with a crown of $20-30$ hooks (Fig. $2 \mathrm{~b})$. The tapeworm showed typical reproductive organs and gravid proglottids (length between $0.68-2.41 \mathrm{~mm}$ and breath ranged from $2.24-4.35 \mathrm{~mm}$ ) containing a large number of eggs (Fig. 2b). Adults tapeworms of $H$. diminuta were $10-35 \mathrm{~cm}$ long with mature and gravid proglottids (length between $3.40-6.80 \mathrm{~mm}$ and breadth between 10.4 - $38.2 \mathrm{~mm}$ ) filled with eggs (Fig. 2c) and
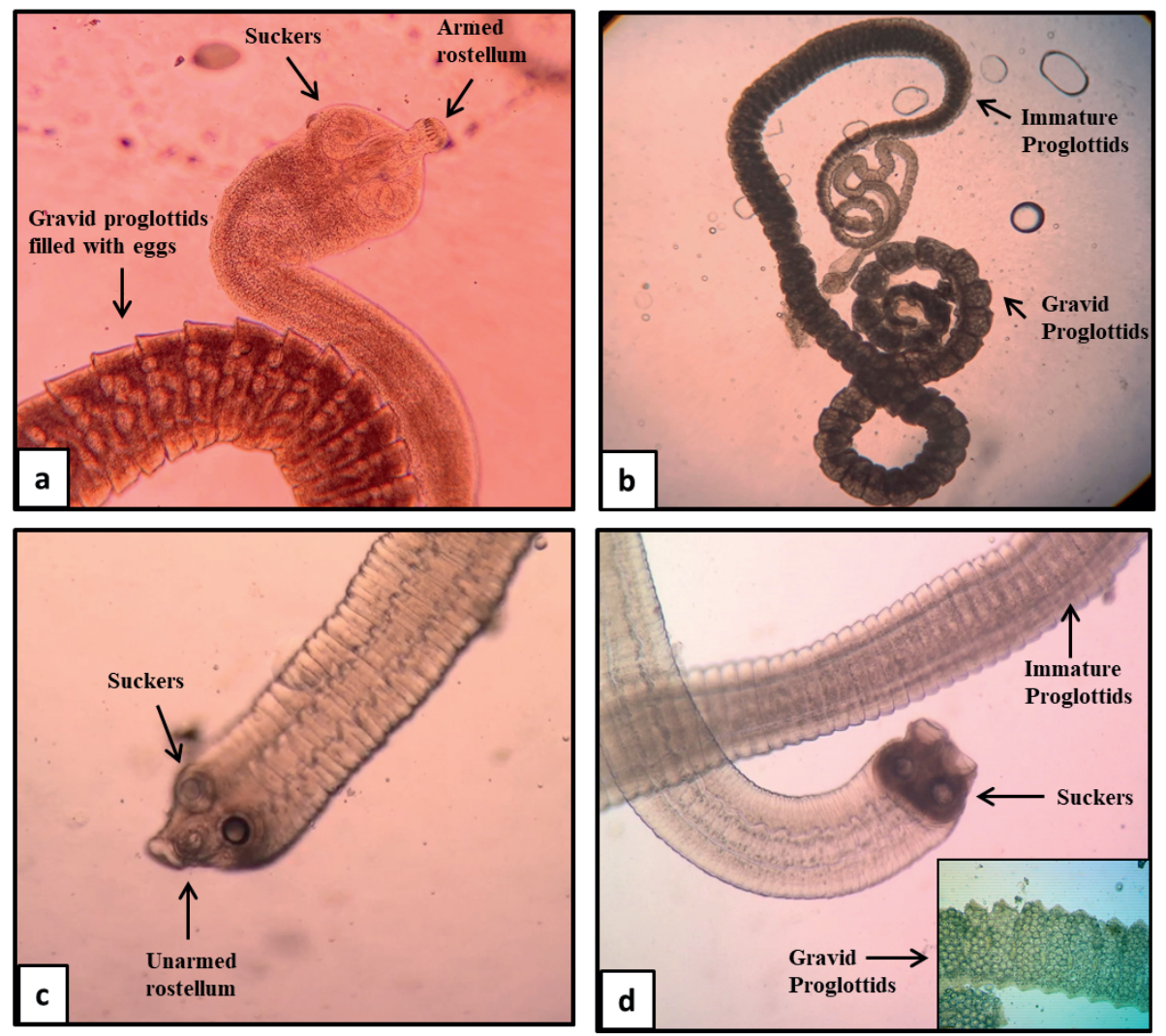

Fig. 2. Tapeworm of $H$. nana showing four suckers (two visible in the view), an armed rostellum and gravid proglottids filled with eggs at 10x (a) and 40x (b); Tapeworm of $H$. diminuta showing four suckers, but only two visible in this view, an unarmed rostellum, mature proglottids and gravid proglottids containing a large number of eggs at $40 x$ ( $c$ and $d)$ 

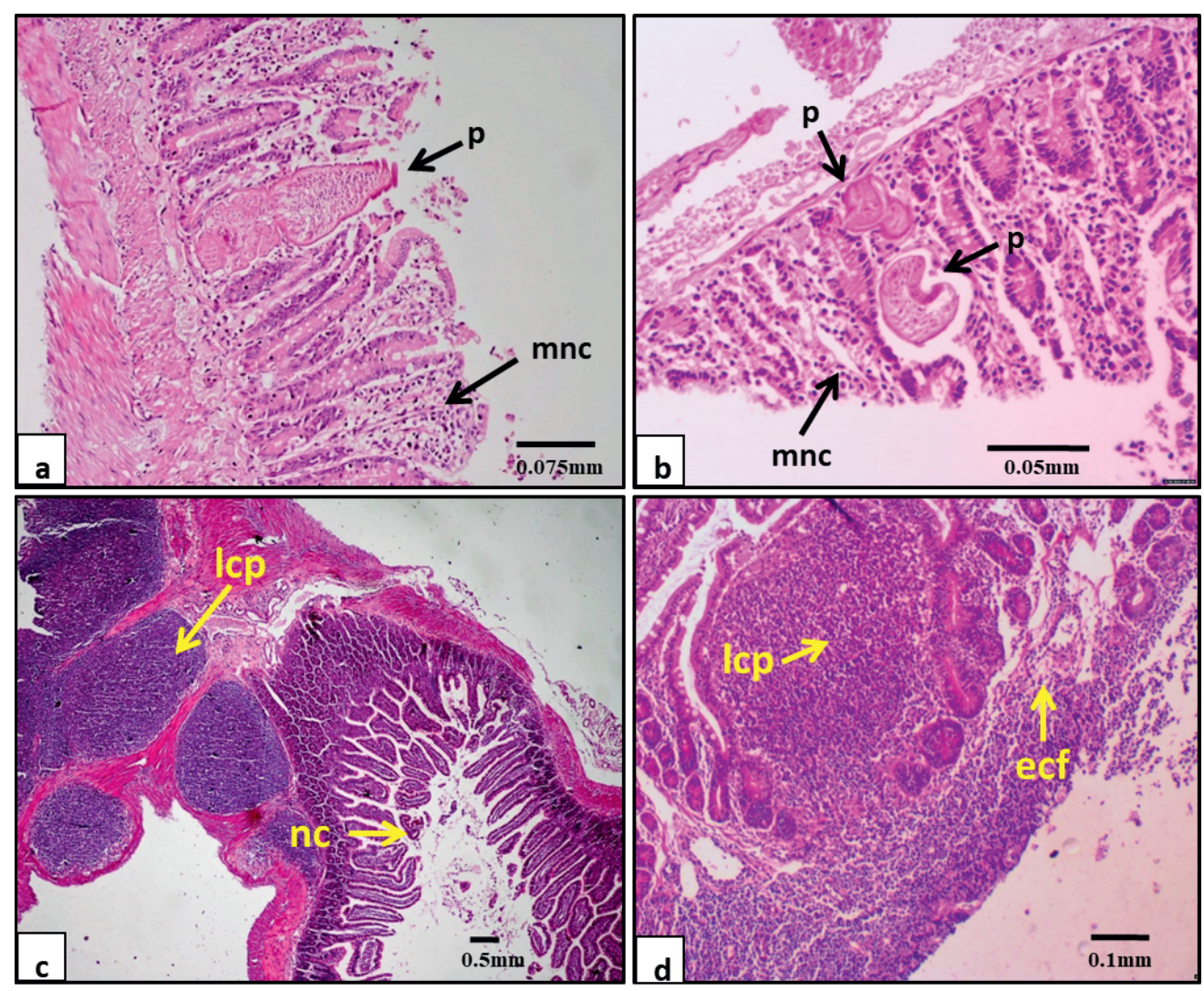

Fig. 3. Section of intestine showing parasitic enteritis (p), scolex of $H$. nana embedded in the mucosa (arrows), sloughing of intestinal mucosa with infiltration of mononuclear cells $(\mathrm{mnc})$ and necrosis $(\mathrm{nc}$ ) of villi at 20x (a)\&40x (b); Section of intestine infected with $H$. nana showing severe mucous degeneration with lymphoid cell proliferation (Icp) andnecrosis in the submucosa (arrow) at $4 x$ (c); Section of intestine infected with $H$. diminuta showing lymphoid cell proliferation (Icp) and eosinophilic cellular infiltration (ecf) in the submucosa at 10x (d)

scolex (length varying from $0.6-1.80 \mathrm{~mm}$ ) having four suckers (diameter between $0.30-0.80 \mathrm{~mm}$ ) and an unarmed rostellum (length ranged of $0.20-0.12 \mathrm{~mm}$ ) (Fig. 2d).

\section{Histopathological analysis}

Histopathologically, the sections of small intestine showed the scolex of $H$. nana embedded in the intestinal mucosa (Fig. 3a). It also showed serrated borders of the tapeworm. Parasitic enteritis, sloughing of intestinal mucosa, necrosis of villi, with infiltration of mononuclear cells in the submucosa were also seen (Fig. 3b). The adjacent parenchyma revealed congestion, necrosis and microgranulomas (Fig. 3c). In present study, the inflammatory reaction recorded around the adult parasites of $H$. diminuta consisted of macrophages and limited eosinophilic cellular infiltration (Fig. 3d). Mild degeneration with lymphoid cell proliferation in the submucosa of small intestine and necrosis of villi was also seen in the rats infected with both the parasites (Fig. $3 c \& d$ ).

\section{Molecular analysis}

The parasites identified by morphological characterisation were confirmed by molecular analysis using bioinformatic tools. On the basis of molecular study, the two cestode species were identified

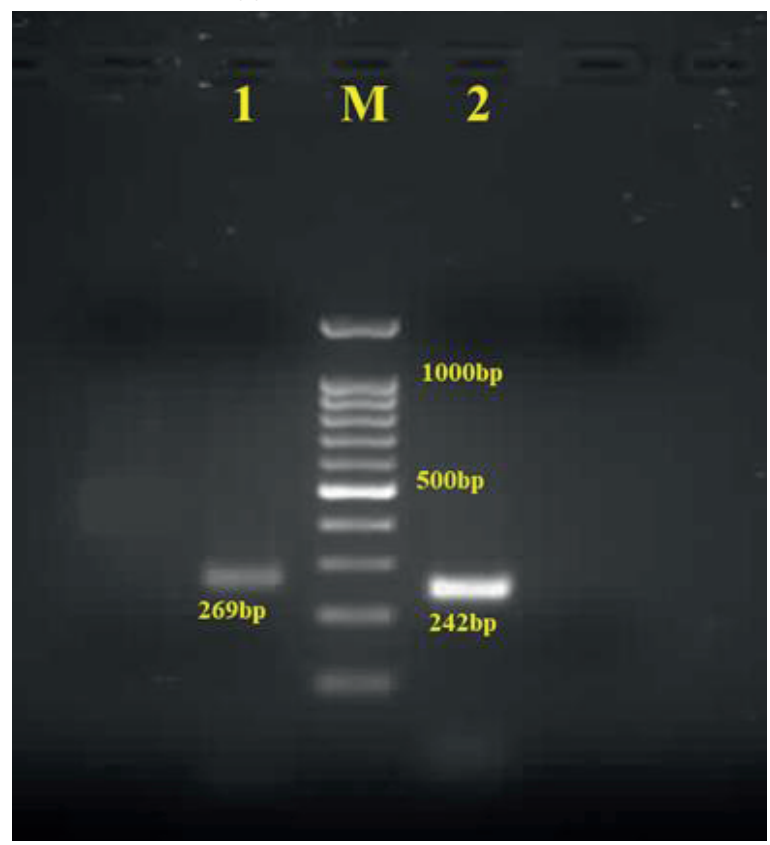

Fig. 4. The PCR amplification of ITS-2 regions of the adult cestodes showing single band of $H$. diminuta (269 Bp) and $H$. nana (242 bp) 


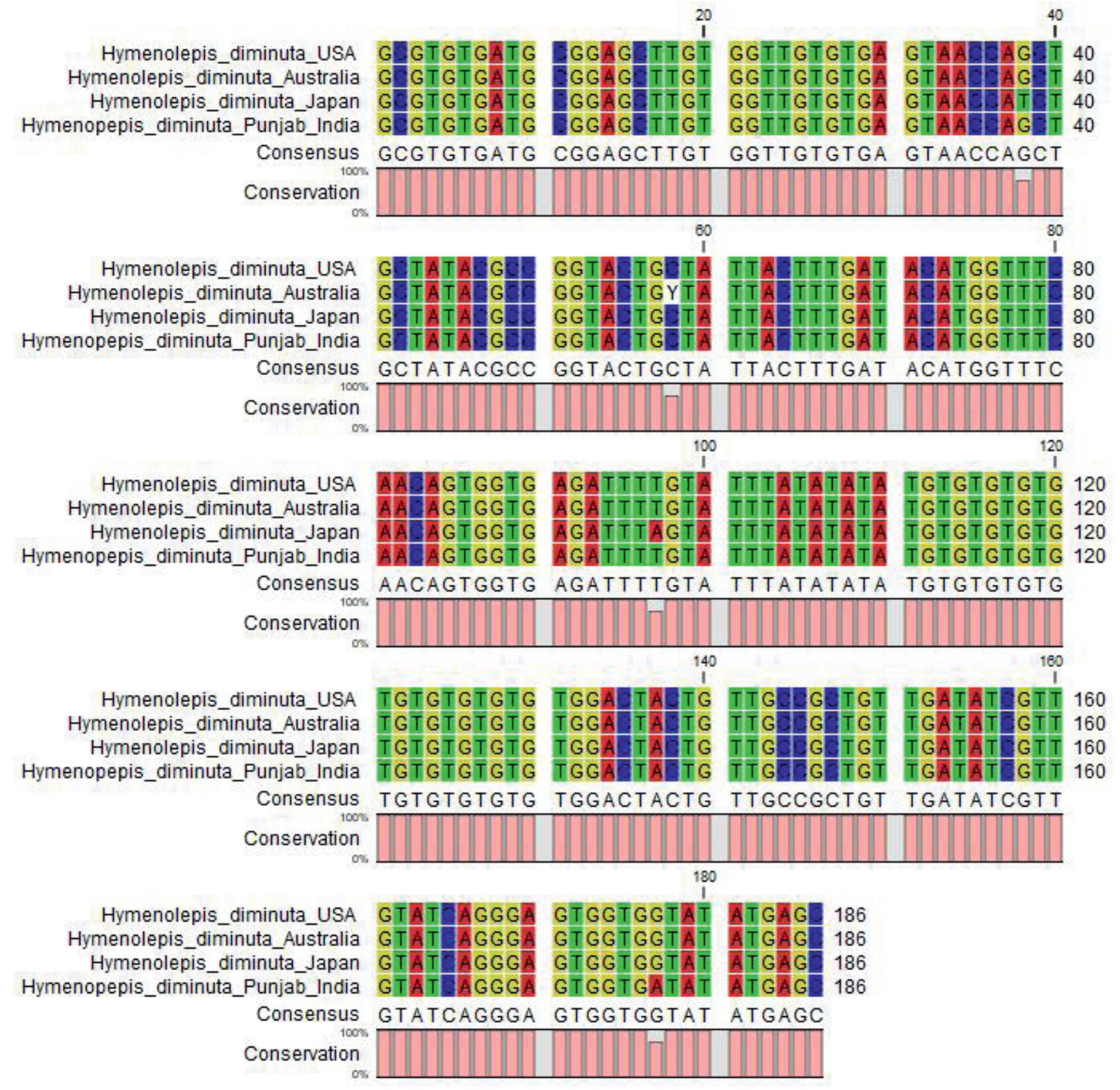

Fig. 5. Multiple alignment of $H$. diminuta (Punjab, India) with different geographical isolates.

as $H$. diminuta and $H$. nana. The internal transcribed spacer-2 (ITS-2) regions of the $H$. diminuta and $H$. nana were successfully amplified. The PCR amplification of these regions showed a single band of approximate size of $269 \mathrm{bp}$ for $\mathrm{H}$. diminuta and $242 \mathrm{bp}$ for H. nana (Fig. 4). The BLAST hits result showed that the sequences of these cestodes are closer to those of genus, Hymenolepis with $99.46 \%$ similarity to $H$. diminuta from USA (Accession number KC990410) and $100 \%$ similarity to $H$. nana from Slovakia, Kosice (Accession number MK874337). Multiple alignment of ITS region of query sequence $(H$. diminuta) with three different geographical isolates (Accession number KC990410, AF461125 and AB494475) showed 98.40 - $99.50 \%$ similarity (Fig. 5). The multiple alignment of ITS region of query sequences $(H$. nana) with three different geographical isolates (Accession number MK874337, LC389873 and KU748350) showed $100 \%$ similarity (Fig. 6). The Nucleotide sequence data of ITS-2 regions of $H$. diminuta and $H$. nana reported in this paper have been submitted to the GenBank with the accession number LC582812 and LC582846, respectively. In the phylogenetic tree constructed (Fig. 7), the query sequence of $H$. diminuta was found placed in the same clade as of $H$. diminuta 


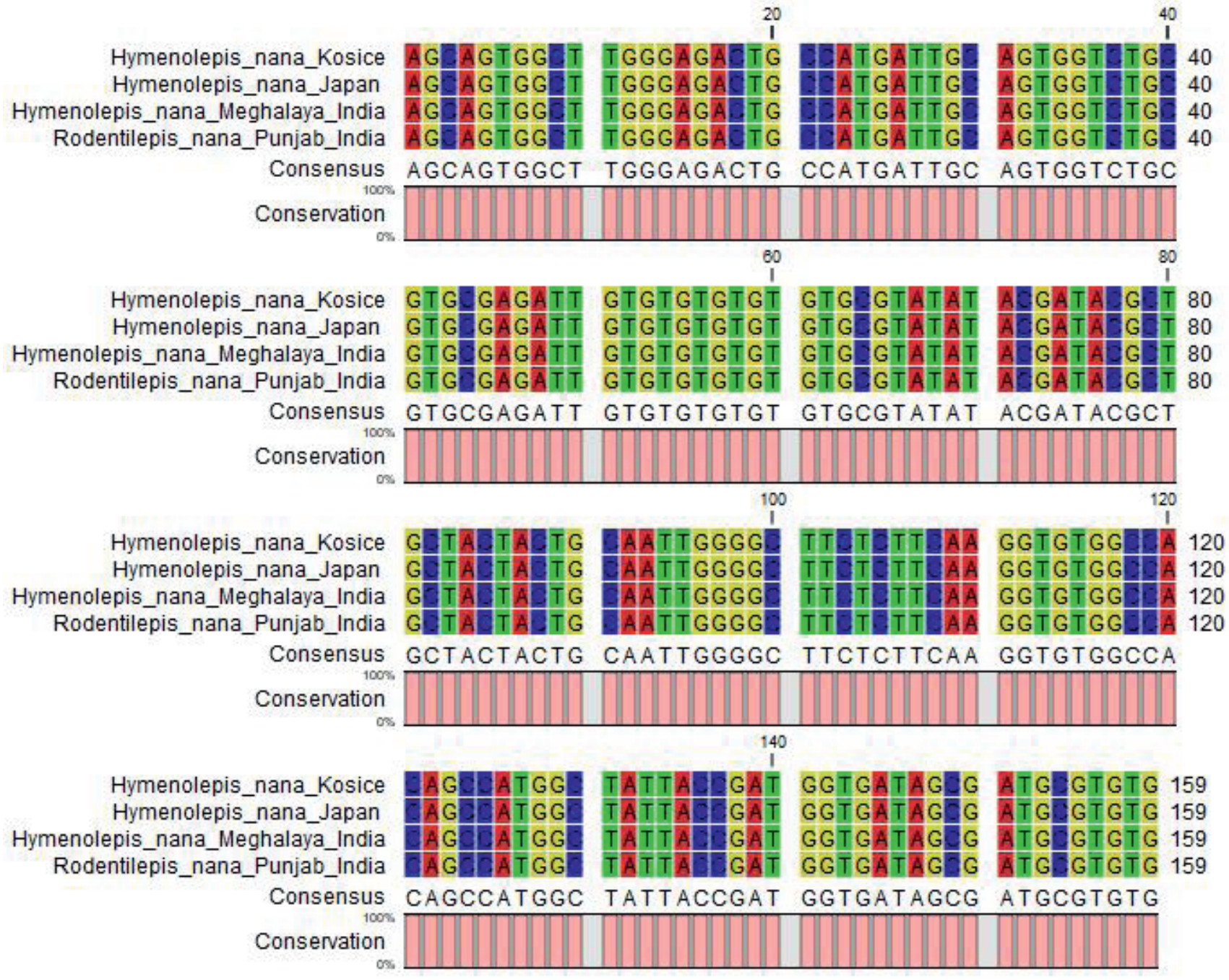

Fig. 6. Multiple alignment of $H$. nana (Punjab, India) with different geographical isolates.

isolates from USA (KC990410 and KC990405) showing bootstrap value of $100 \%$. The query sequence of $H$. nana was found placed in the same clade as of $H$. nana isolates from Kosice (MK874337) showing bootstrap value of $100 \%$ (Fig. 8).

\section{Discussion}

Hymenolepiasis caused by both the cestodes species $(H$. nana and $H$. diminuta) having wide range of prevalence values, is more common in areas of poor structural and socio-environmental conditions and where there is close contact between rodents and humans. Dispersal of the eggs of $H$. diminuta in the environment via beetle faeces (Pappas \& Barley, 1999, Zhong et al., 2013, Makki et al., 2017) represents an additional source of infection. More than 21 million people worldwide, especially from tropical and subtropical regions have been reported to suffer from Hymenolepiasis infection. The prevalence of Hymenolepis spp. in urban rodents is of particular interest due to auto-infection. The ovum of Hymenolepis spp. hatches in the intestine of the host without being passed outside and grows into an adult worm. This increases the number of adult worms in the hosts' intestine, thereby increasing the chances of environmental contamination with parasite eggs/ova in the stool (Tijjani et al., 2020). Affected populations have been largely under reported due to poor diagnosis of gastrointestinal parasites which is traditionally based on faecal microscopy (Stensvold et al., 2007), but in our study, it was found that the number of positive animals were same when evaluated by both the coproparasitoscopical technique and gastrointestinal examination. Animals with faecal samples positive for eggs, were also found infected with adults. So, our study also records that, the coproparasitoscopical technique has good diagnostic sensitivity and specificity for cestodes.

In the unusual life cycle of $H$. nana, where no intermediate host is essential, man is probably at the main risk of infection. Hyme- 


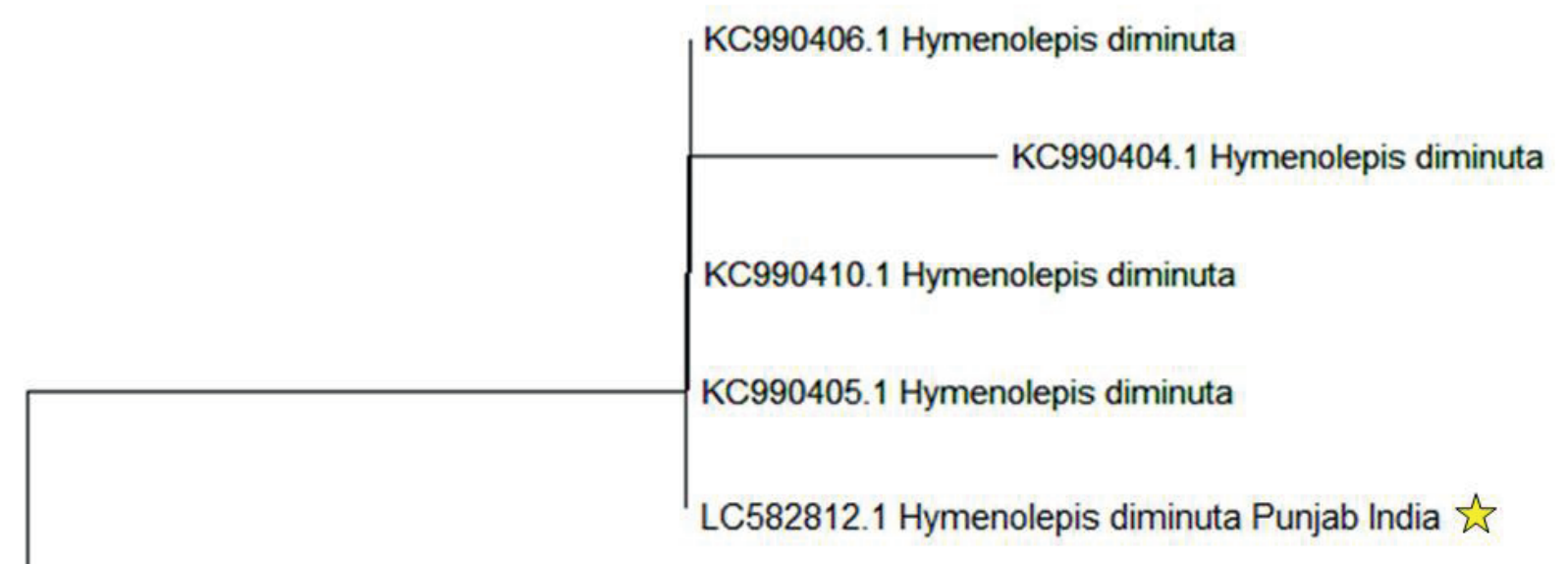

AB494474.1 Hymenolepis diminuta

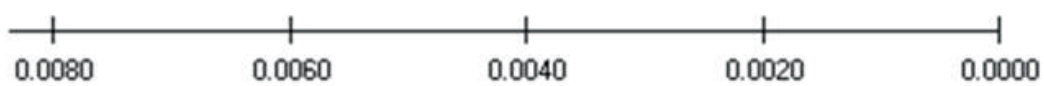

Fig. 7. Phylogenetic tree of $H$. diminuta (Punjab, India) constructed using Maximum Likelihood method in MEGAX software.

nolepiasis due to $H$. nana has been reported to affect about 36 million people worldwide (Peters \&Pasvol, 2002). Although young children can be infected with $H$. nana eggs from rodent sources, this type of infection is probably less common in them (Faust et al., 1962).

These species have been recorded in $R$. rattus, $R$. norvegicus and $B$. bengalensis in different environmental conditions mostly in urban areas (Battersbyet al., 2002; Abu-Madi et al., 2005, Easterbrook et al., 2007; Kataranovski et al., 2011; Zain et al.,2012; Ahmad et al., 2014; Singla et al., 2016). The present study showed single as well as concurrent infection of $H$. nana and $H$. diminuta thus representing a higher risk to public health (Stojcevic et al., 2004; Waugh et al., 2006; Easterbrook et al., 2007; Hancke et al., 2011).

The infection rate $(66.95 \%)$ of $H$. nana (including both single and concurrent infection) during the present investigation is very close to that reported in earlier studies conducted by Gilioli et al. (2000) and Tanideh et al. (2010) i.e. $53.3 \%$ and $50-66 \%$, respectively in different laboratory rodents. Rasti et al. (2000) found $56.7 \%$ of the rodents, live trapped from the semi-desert, urban and rural areas of Kashan (Iran) infected with helminthes including $H$. nana. In contrast to our study, much lower incidence had been reported by many researchers i.e. $12.5 \%$ in rodents of South West Iran (Kia et al., 2001) and $11.0 \%$ in rats at U.K. (Webster \& MacDonald, 1995).

A higher infection rate of $53.61 \%$ for $\mathrm{H}$. diminuta (including both single and concurrent infection) was seen in the present study in contrast to lower infection rates of $30.7,36.9,35.8,38.0$ and
$33.33 \%$ observed by Kassan \& Assefa (2000) from Addis Ababa (Ethiopia), Stojcevic et al. (2004) at Croatia, Abu-Madiet al. (2005) at Doha Qatar, Kumarasinghe et al. (2006) in Sri Lanka and Paramasvaran et al. (2009) at Kuala Lumpur, respectively in different species of rodents. Much lower infection rates of $H$. diminuta (11.1 and $3.8 \%$ ) were reported by Kia et al. (2001) and Waugh et al. (2006), respectively. In a similar study conducted at Faisalabad (Pakistan), the incidence of $\mathrm{H}$. diminuta observed by Rafique et al. (2009) ranged between $20-60 \%$ and is comparable with our findings.

Overall investigation on the effect of these parasitic infections on pathophysiology of the host revealed that these parasites cause pathogenic and degenerative effects on the intestinal tissue of the rodents. Histopathological observations of small intestine infected with Hymenolepis spp. found in the present study are similar to those reported by Goswami et al. (2011). They also observed similar degenerative changes in the mucosa and submucosa of small intestine infected with adult worms of Hymenolepis spp. along with scolex of tapeworm attached with intestinal mucosa (Goswami et al., 2011). Investigations on the effect of parasitic infections on pathophysiology of the host have revealed that rodents may serve as reservoirs of these parasitic infections without having much pathogenic effect (Singla et al., 2016).

The observations of the present study related to comparatively higher incidence of cestodes in summer season and in residences/ shops etc. are similar to those of other workers (Hildebrand 2008, Kataranovski et al., 2011). Fichet et al. (2003), however, have reported higher occurrence of helminthes in monsoon as compared 

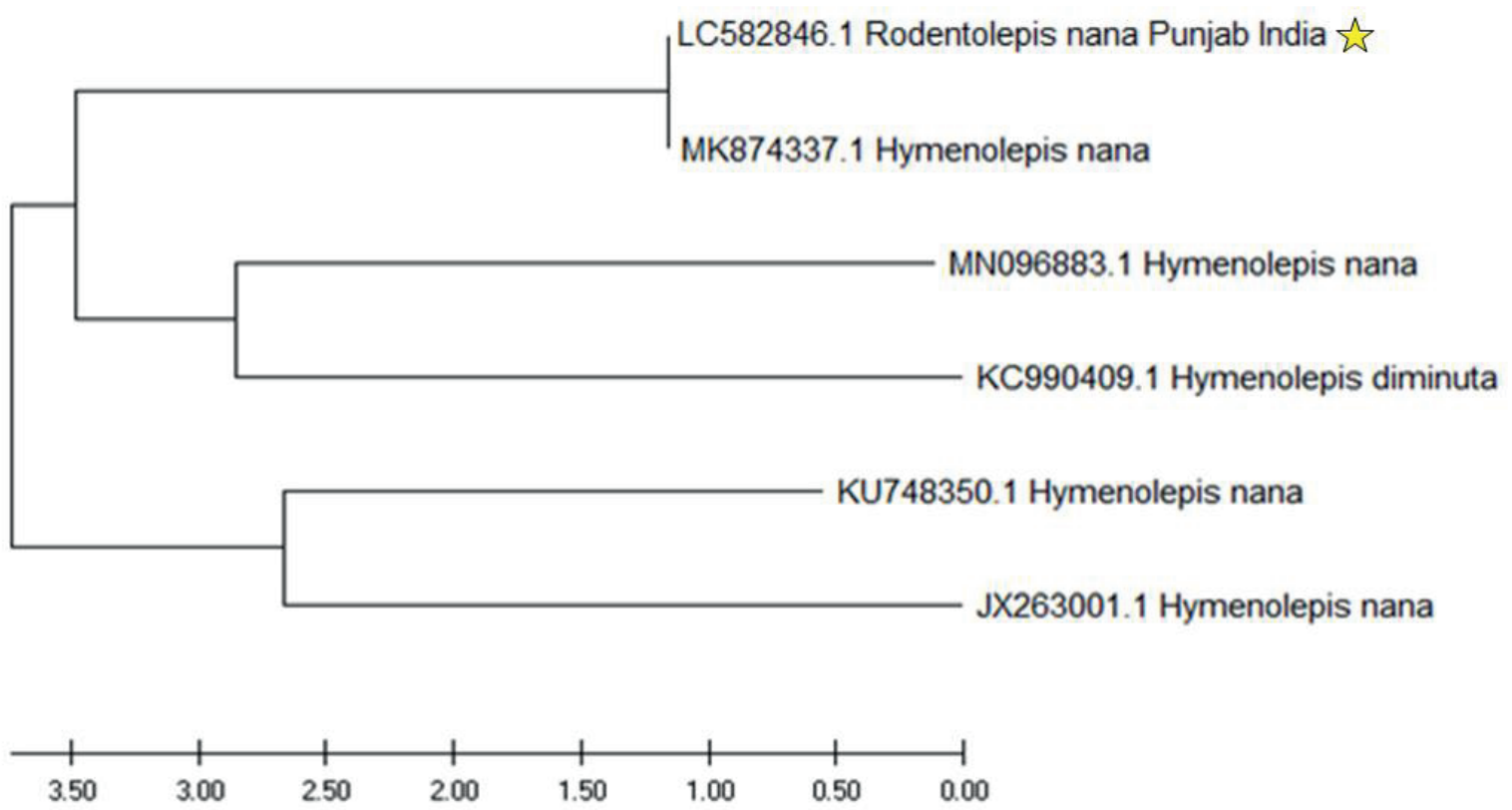

Fig. 8. Phylogenetic tree of $H$. nana (Punjab, India) constructed using Maximum Likelihood method in MEGAX software.

to other two seasons. The temperature and the relative humidity during summer and monsoon seasons may be favourable for developmental stages of the parasites (Kreppel et al., 2016) and hence more chances of infection. Similarly, the populations of arthropod intermediate hosts could also be affected by the degree of urbanization (Hancke \& Suarej, 2015).

Similar to present study, Sinniah et al. (1999) and Kia et al. (2010) also reported slightly higher infection rate in male rats. In contrast, some workers observed significant influence of sex on prevalence rate and reported higher prevalence of $H$. diminuta and $H$. nana in males than in female rats (Yen et al., 1996, Goswami et al., 2009, Onyenwe et al., 2009, Ahmad et al., 2014). This may be due to the fact that males have larger territories (Brown et al., 1994) and overlapping home ranges (Ims, 1987) than females thereby increasing their exposure time to infection.

The worm burdens of $H$. diminuta and $H$. nana in adult rats were almost three times than in juveniles in the present investigation which is in accordance with the studies conducted by Stojcevic et al. (2004), Abu-Madi et al. (2005) and Gomez et al. (2008). Similar to present study, Ahmad et al. (2014) observed significant differences in prevalence of $H$. nana between adult $(66.5 \%)$ and juvenile $(6.8 \%)$ rats and mice. Maintenance of higher infection in adults than young rats may be due to more exploratory behaviour of adults in search of food and shelter thus having longer exposure time of encountering the infection (Easterbrook et al., 2007, Ahmad et al., 2014).

Similar to present study, Tresnani et al. (2016) detected Hymenolepis spp. through ITS gene PCR analysis. Yang et al. (2017) conducted both morphological and molecular study (of mitochondrial cytochrome-c oxidase subunit 1 gene (cox 1 ) and the internal transcribed spacer 2 (ITS-2) region) to identify Hymenolepis spp. from black rats in China. Sharma et al. (2016) did differential molecular diagnosis of $H$. diminuta and $H$. nana based on ITS2 gene and reported that the two species are distantly related and have diverged independently from the ancestral lineage.

\section{Conclusions}

Based on this comprehensive study it is concluded that rodent populations at different localities as well as structures are infected by both of these zoonotic cestodes as confirmed by combination of morphometric followed by molecular characterisation for the first time in the region. Hence these synanthropes may serve as rich and active reservoir threat of Hymenolepis species infection dissemination to human beings living in close association with them in a polluted, un-hygienic environment. Because of the close association with human habitations, $R$. rattus and $B$. bengalensis may act as an important source of zoonotic infections and thus education about proper hygiene, clean environment and good food eating and storage habits are important in avoiding direct or indirect contact with excrements and carcasses of these pest and vector species.

\section{Conflict of interest}

Authors state no conflict of interest. 


\section{Acknowledgement}

Authors are thankful to the Indian Council of Agricultural Research, New Delhi, India for providing funds in the form of All India Network Project on Vertebrate Pest Management (Rodent Control) at Punjab Agricultural University, Ludhiana, India.

\section{References}

Aboel-Hadid, S.H., Allam, G.A. (2007): Investigation of helminth parasitic infection of laboratory animals (rats \& mice) with special reference to control of Hymenolepis nana as a zoonotic parasite. Egypt. J. Exp. Biol. (Zool.), 3: $83-89$

Abu-Madi, M.A., Behnke, M., Mikhall, M., Lewis, J.W., Al-KaAbI, M.L. (2005): Parasite populations in the brown rat Rattus norvegicus from Doha, Qatar between years: the effect of host age, sex and density. J. Helminthol., 79: 105 - 111. DOI: 10.1079/joh2005274

Ahmad, M.S., Maqbool, A., AnJum, A.A., Ahmad, N., Khan, M.R., SulTANA, R., ALI, M.A. (2014): Occurrence of Hymenolepis diminuta in rats and mice captured from urban localities of Lahore, Pakistan. J. Anim. Plant Sci., 24(2): 392 - 396

Alvez, J.R., Macedo, H.W., Ramos, A.N., Ferreira, L.F., Goncalves, M.L., Araujo, A. (2003): Intestinal parasite infections in a semiarid area of Northeast Brazil: Preliminary findings differ from expected prevalence rates. Cad. Saude Publica., 19(2): 667 - 670. DOI: 10.1590/S0102-311X2003000200034

BAHADIR, G.N. (2002): Analysis of the crude antigen of Hymenolepis nana from mice by SDS-PAGE and the determination of specific antigens in protein structure by western blotting. Turkish $\mathrm{J}$. Vet. Anim. Sci., 26: 1067 - 1071

Battersby, S.A., Parson, S.R., Webster, J.P. (2002): Urban rat infestation and the risk to public health. J. Environ. Health Res., 1(2): 4

Brown, E.D., Macdonald, D.W., Tew, T.E., Tood, I.A. (1994): Apodemus sylvaticus infected with Heligmosomoides polygyrus (Nematoda) in an arable ecosystem: epidemiology and effects of infection on the movements of male mice. J. Zool., 234: 623 -640 Bush, A., LAFFERTY, K., LOTZ, J., SHOSTAK, A. (1997): Parasitology meets ecology on its own terms: Margolis et al. Revisited. J. Parasitol., 83(4): 575-583. DOI: $10.2307 / 3284227$

Chandler, A.C. (1923): The distribution of Hymenolepis diminuta infectionsin India and discussion of its epidemiological significance. Indian J. Med. Res., 14: 973

CROMPTON, D.W. (1999): How much human helminthiasis is there in the world? J. Parasitol., 85(3): 397 - 403.DOI: 10.2307/3285768 Easterbrook, J.D., Kaplan, J.B., Vanasco, N.B., Reeves, W.K., Purcell, R.H., Kosoy, M.Y., Glass, G.E., Watson, J., Klein, S.L. (2007): A survey of zoonotic pathogens carried by Norway rats in Baltimore, Maryland, USA. Epidemiol. Infect., 135: 1192 - 1199. DOI: $10.1017 /$ S0950268806007746

Faust, E.C., BEAVER, P.C., Jung, R.C. (1962): Animal agents and vectors of human diseases. $2^{\text {nd }}$ edition, Philadelphia, Lea and
Febiger, $33-35$ pp.

Felsenstein, J. (1985): Confidence limits on phylogenies: An approach using the bootstrap. Evol., 39: 783 - 791. DOI: 10.1111/ j.1558-5646.1985.tb00420.x

Fichet, C.E., Giraudoux, P., Quere, J.P., Ashford, R.W.,DelatTRE,P. (2003): Is the prevalence of Taenia taeniaeformis in Microtusarvalisdependent on population density. J. Parasitol., 89(6): 1147 - 1152. DOI: 10.1645/GE-3158

Fitte, B., Robles, M.R., Dellarupe, A., Unzaga, J.M., Navone, G.T. (2018): Hymenolepis diminuta and Rodentolepis nana (Hymenolepididae: Cyclophyllidea) in urban rodents of Gran La Plata: association with socio-environmental conditions. J. Helminthol., 92(5): 549 - 553. DOI: 10.1017/S0022149X17000864

Giloli, R., Andrade, L.A.G., Passos, L.A.C., Silva, F.A., Rodrigue, D.M., Guaraldo, A.M.A. (2000): Parasite survey in mouse and rat colonies of Brazilian laboratory animal houses kept under different sanitary barrier conditions. Arq. Bras. Med. Vet. Zoo., 52: 33 - 37. Doi: 10.1590/S0102-09352000000100009

Gomez, V.E., Robles, M.R., Busch,M. (2008): Helminth communities and host parasite relationships in argentine brown rat (Rattus norvegicus). Helminthologia, 3: 126 - 129. DOI: 10.2478/s11687008-0024-1

Goswami, R., Singh, S.M., KataRIA, M., SomvanshI, R. (2011): Clinicopathological studies on spontaneous Hymenolepis diminuta infection in wild and laboratory rats. Braz. J. Vet. Pathol., 4(2): $103-111$

Goswaml, R., Somvansh, R., Singh, S.M., Sarman,S. (2009): A preliminary survey on incidence of helminthic and protozoal diseases in rats. Indian J. Vet.Pathol., 33: 4750 - 4758

Hancke, D., Navone, G.T., SuAREZ, O.V. (2011): Endoparasite community of Rattus norvegicus captured in a Shantytown of Buenos Aires City, Argentina. Helminthologia, 48: 167 - 173. DOI: 10.2478/ s11687-011-0025-3

Hancke, D., SaURez, O. (2015): Infection levels of the cestode Hymenolepis diminuta in rat populations from Buenos Aires, Argentina. J. Helminthol., 90(2): 1 - 7. DOI: 10.1017/S0022149X15000164

Hasegawa, M., KISHINo, H., Yano, T. (1985): Dating the human-ape split by a molecular clock of mitochondrial DNA. J. Mol. Evol., 22: $160-174$

HILDEBRAND, J. (2008): The helminth fauna structure of wild rodents from differential sites of Wroclaw area. Wiad.Parazytol., 54(3): $249-250$

Hsu, C.K. (1980): Parasitic diseases: How to monitor them \& their effects on research. Lab Anim., 14: 48 - 53

IMS, R. A. (1987): Responses in spatial organization and behaviour to manipulations of the food resource in the vole Clethrionomys rufocanus. J. Anim. Ecol., 56: 585 - 596

KandI, V., KoKa, S., Bhoomigarl, M. (2019): Hymenolepiasis in a pregnant woman: a case report of Hymenolepis nana infection. Cureus, 11(1): e3810. DOI: 10.7759/cureus.3810

Kassan, M., Assefa, T. (2000): Prevalence of intestinal helminthic infections among house hold rats in Addis Ababa. Ethiop. J. Health 
Sci., 23(1): $115-120$

Kataranovski, M., Mirkov, I., Beli, S., Popov, A., Petrović, Z., GaČIĆ, Z., KataranovsKI, D. (2011): Intestinal helminth infection of rats (Rattus norvegicus) in the Belgrade area (Serbia): the effect of sex, age and habitat. Parasite, 18: 189 - 196. DOI: 10.1051/ parasite/2011182189

Kia, E.B., Homayouni, M.M., Farahnak, A., Mohebali, M., Shojal, S. (2001): Study of endoparasites of rodents and their zoonotic importance in Ahvaz, South West Iran. Iranian J. Public Health, 30(12): $49-52$

Kia, E.B., Shahryary-Rad,E., Mohebali, M., Mahmoud, M.,Mobedi, I., Zahabiun, F., Zarel, Z.,Miahipoor, A., Mowlavi, G.H., Akhavan, A.A., VAtANDOOSt, H. (2010): Endoparasites of rodents and their zoonotic importance in Germi, Dashte-Mogan, Ardabil Province, Iran. Iran. J. Parasitol., 5(4): $15-20$

Kreppel, K. S., Telfer, S., Rajerison, M., Morse, A., Baylis, M. (2016): Effect of temperature and relative humidity on the development times and survival of Synopsyllus fonquerniei and Xenopsylla cheopis, the flea vectors of plague in Madagascar. Parasit Vectors 9. DOI: 10.1186/s13071-016-1366-z

Kumar, S., St Echer, G., Li, M., Knyaz, C., Tamura, K. (2018): MEGA X: Molecular Evolutionary Genetics Analysis across computing platforms. Mol. Biol. Evol. 35: 1547 - 1549. DOI: 10.1093/ molbev/msy096

Kumarasinghe, K.M.R.S., Premajtith, H.A.D.B., WiJesundara, R.R.M.K.K., AJAPAKSHE, R.P.V.J. (2006): Prevalence of zoonotic blood protozoans and gastrointestinal helminthes in rats (Genus: Rattus) and mice (Genus: Mus) in Sri Lanka. Proc. Peradeniya Univ. Res. Sess., 62 pp.

LuNA, L. G. (1968): Manual of Histologic Staining Methods of the Armed Forces Institute of Pathology, 3rd ed. McGraw-Hill Book Company, New York, 258

MakkI, M.S., Mowlavi, G., ShahbazI, F., Reza, M.A., Najafi, F., HosSEINI-FARASH, B.R. (2017): Identification of Hymenolepis diminuta cysticercoid larvae in Tribolium castaneum (Coleoptera: Tenebrionidae) beetles from Iran. J. Arthropod-Borne Dis., 11(2): 338 - 343 Malsawmtluangl, C., Prasad, P.K., Biswal, D.K., Tandon, V. (2011): Morphological and molecular identification of the metacestode parasitizing the liver of rodent hosts in bamboo growing areas of Mizoram, northeast India. Bioinformation, 7(8): 393 - 399. DOI: 10.6026/97320630007393

Marangi, M., Zechinl, B., Flleti, A., Quarantam, G., Aceti, A. (2003): Hymenolepis diminuta infection in a child living in the urban area of Rome, Italy. J. Clin. Microbiol., 41: 3994 - 3995. DOI: 10.1128/ jcm.41.8.3994-3995.2003

MeerbuRg, B.G. (2010): Rodents are a risk factor for the spreading of pathogens on farms. Vet. Microbiol., 142(3-4): $464-465$. DOI: 10.1016/j.vetmic.2009.06.038

Meerburg, B. G., Singleton, G. R., Killstra, A. (2009): Rodent-borne diseases and their risks for public health. Crit. Rev. Microbiol., 35(3): 221 - 270. DOI: 10.1080/10408410902989837 Mejia, R., Vicuña, Y., Broncano, N., Sandoval, C., Vaca, M., Chico,
M., Cooper, P.J., Nutman, T.B. (2013): A novel, multi-parallel, real-time polymerase chain reaction approach for eight gastrointestinal parasites provides improved diagnostic capabilities to resource-limited at-risk populations. Am. J. Trop. Med. Hyg., 88(6): 1041 - 1047. DOI: 10.4269/ajtmh.12-0726

MIRDHA, B.R., SamantraY, J.C. (2002): Hymenolepis nana: a common cause of paediatric diarrhoea in urban slum dwellers in India. J. Trop. Pediatr., 48(6): 331 - 334. DOI: 10.1093/tropej/48.6.331 MORGAN, J.A.T., BLAIR, D. (1998): Relative merits of nuclear ribosomal internal transcribed spacers and mitochondrial CO1 and ND1 genes for distinguishing among Echinostomaspecies (Trematoda). Parasitol., 116: 289 - 297. DOI: 10.1017/s0031182097002217

Onyenwe, I.W., Ihedioha, J.I., EZEme, R.I. (2009): Prevalence of zoonotic helminths in local house rats (Rattus rattus) in Nsukka, eastern Nigeria. Anim. Res. Int., 6(3): 1040 - 1044. DOI: 10.4314/ ari.v6i3.55977

Pappas, P.W., Barley, A.J. (1999): Beetle-to-beetle transmission and dispersal of Hymenolepis diminuta (Cestoda) eggs via the feces of Tenebriomelitor. J. Parasitol., 85: $384-385$

Paramasvaran, S., Sani, R.A., Hassan, L., Hanjeet, K., Krishnasamy, M., John, J., Santhana, R., Sumarni, M.G., Lim, K.H. (2009): Endoparasite fauna of rodents caught in five wet markets in Kuala Lumpur and its potential zoonotic implications. Trop. Biomed., 26: $67-72$

Peters, W., Pasvol, G. (2002): Tropical Medicine and Parasitology. $5^{\text {th }}$ edition, Mosby, London, $202-207 \mathrm{pp}$.

Rafique, A., Rana, A., Khan, H.A.,Sohall, A. (2009): Prevalence of some helminths in rodents captured from different city structures including poultry farms and human population of Faisalabad, Pakistan. Pak. Vet. J., 29: 141 - 144

Rasti, S., Moubedi, I., Dehghani, R., Drodgar, A. (2000): The survey of gastrointestinal helminths of mice in Kashan. J. Fac. Vet. Med. Univ. Tehran, 55(4): 57 - 59

Sharma, S., LYNGdoh, D., RoY, B., TANDon, V. (2016): Differential diagnosis and molecular characterization of Hymenolepis nana and Hymenolepis diminuta (Cestoda: Cyclophyllidea: Hymenolepididae) based on nuclear rDNA ITS2 gene marker. Parasitol. Res.,115: 4293 - 4298 (2016). DOI: 10.1007/s00436-016-5210-3 Singla, L.D., Singla, N., Parshad, V.R., Juyal, P.D., Sood, N.K.(2008a): Rodents as reservoirs of parasites in India. Integr. Zool., 3(1): 21 - 26. DOI: 10.1111/j.1749-4877.2008.00071.x

Singla, N., Dhar, P., Singla, L.D., Gupta,K. (2016): Patho-physiological observations in natural concurrent infections of helminth parasites of zoonotic importance in the wild rodents, Bandicota bengalensis. J.Parasit. Dis., 40(4): 1435 - 1442. DOI 10.1007/ s12639-015-0709-6

SINGLA, N., SINGLA, L.D., KAUR, R. (2008b): Rodents as museum of helminth parasites of public health importance in Punjab, India. Int. J. Infect. Dis., 12: e381 - 382. DOI: 10.1016/j.ijid.2008.05.1008 SinNIAH, B., SINGH, M., ANUAR, K. (1999): Preliminary survey of Capillaria hepatica (Bancroft, 1893) in Malaysia. J. Helminthol., 53(2): 147 - 152. DOI: 10.1017/s0022149x00005897 
SoulsBY, E.J.L. (1982): Helminths, Arthropods and Protozoa of Domesticated Animals, $7^{\text {th }}$ edition, London, Balliere Tindall.

Stensvold, C.R., Arendrup, M.C., Jespersgaard, C., Mølbak, K., NieLSEN, H.V. (2007): Detecting Blastocystis using parasitologic and DNA-based methods: a comparative study. Diagn. Microbiol. Infect. Dis. 59: 303 - 307. DOI: 10.1016/j.diagmicrobio.2007.06.003 Stojcevic, D., Mihluevic, Z., Marnculic, A. (2004): Parasitological survey of rats in rural regions of Croatia. Vet. Med. Czech, 49(3): 70 - 74. DOI: 10.17221/5679-VETMED

Tanideh, N., Sadjuadi, S.M., Mohammadzadeh, T. Mehrabani, D. (2010): Helminthic Infections of laboratory animals in animal house of Shiraz University of Medical Sciences and the potential risks of zoonotic infections for researchers. Iranian Red. Crescent. Med. J., 12(2): $151-157$

TiJjani, M., Majida, R.A., Abdullahia, S.A., Aunyaha, N.Z. (2020): Detection of rodent-borne parasitic pathogens of wild rats in Serdang, Selangor, Malaysia: A potential threat to human health. Int. J. Parasitol. Parasites. Wildl., 11: 174 - 182. DOI: 10.1016/j.jppaw.2020.01.008

TresnanI, G., HadI, I., Wayan, S.I. (2016): Parasites of house rats (Rattus rattus complex) in Mataram, Lombok, Indonesia. J. Vet. Parasitol., 30(1): $35-38$

Watwe, S., Dard, C.K. (2008): Hymenolepis diminuta in a child from rural area. Indian J. Pathol. Microbiol., 51: 149 - 151. DOI: 10.4103/0377-4929.40431
Waugh, C.A., Lindo, J.F., Foronda, P., Angeles-Santana, M., LorenZo-Morales, J., Robinson, R.D. (2006): Population distribution and zoonotic potential of gastrointestinal helminths of wild rats Rattus rattusand Rattus norvegicus from Jamaica. J. Parasitol., 92: 1014 - 1018. DOI: 10.1645/GE-795R1.1

Webster, J.P., MACDONALD, D.W. (1995): Parasites of wild brown rats (Rattus norvigicus) on UK farms. J. Parasitol., 111(3): 247 - 255. DOI: 10.1017/s0031182000081804

Whary, M. T., Baumgarth, N., Fox, J. G., BRthold, S. W. (2015): Biology and diseases of mice. In: Laboratory Animal Medicine, 3 ed. Pp. 43 - 149. American College of Laboratory Animal Medicine, Academic Press. DOI: 10.1016/B978-0-12-409527-4.00003-1

Yang, D., Zhao, W., Zhang, Y. Liu, A. (2017): Prevalence of Hymenolepis nana and $H$. diminuta from Brown Rats (Rattus norvegicus) in Heilongjiang Province, China. Korean J. Parasitol., 55(3): 351 - 355. DOI: 10.3347/kjp.2017.55.3.351

Yen, C.M., Wang, J.J., Lee, J.D., Chen, Y.P., Chen, E.R. (1996): Parasitic infections among wild rats from two areas of Kaohsiung. J. Med. Sci., 12(3): 145 - 149. PMID: 8709181

ZAIN, S.N.M., BEHNKE, J.M., LEWIS, J.W. (2012): Helminth communities from two urban rat populations in Kuala Lumpur, Malaysia. Parasit Vectors, 5: 1 - 23. DOI: 10.1186/1756-3305-5-47

Zhong, D., Pal, A., Wang, M.H., Keech, N., Yan, G. (2013): Finescale analysis of parasite resistance genes in the red flour beetle, Tribolium castaneum. Genetics, 195(1): 253 - 261. DOI: 10.1534/ genetics.113.153205 